ПОЛИТИКО-ПРАВОВЫЕ И КУЛЬТУРНЫЕ ФАКТОРЫ ХОЗЯЙСТВЕННОГО РАЗВИТИЯ СИБИРИ

DOI 10.17150/978-5-7253-3001-4.41

В.Н. КАЗАРИН

УДК 342.5/6[(47)+(57)](091)

ББК X620.61(2P)

\title{
СТАНОВЛЕНИЕ ПРАВОВОГО СТАТУСА МЕСТНЫХ ОРГАНОВ ВЛАСТИ В РСФСР В 1920-е ГОДЫ
}

Анализируется становление и эволюция нормативно-правовой основы организации, полномочий, ответственности и сфер деятельности местных органов власти в РСФСР в 1920-е гг.

Ключевые слова: декреты, постановления, циркулярные письма, местные органы власти, РСФСР.

V.N. KAZARIN

N.V. SILJANKIN

\section{BECOMING OF THE LEGAL STATUS OF LOCAL AUTHORITIES IN RSFSR IN $1920^{\mathrm{TH}}$}

Becoming and evolution of a regulatory-legal basis of the organization, powers, the responsibility and fields of activity of local authorities in RSFSR in $1920^{\text {th }}$ is analyzed.

Keywords: decrees, decisions, circular letters, local authorities, RSFSR.

В начале 1920-х гг. ни в центре, ни на местах не было четкого плана построения системы органов советской власти. Отсутствовали единые требования и правила выборов в местные Советы. Кроме этого, имелись смутные представления о структуре отделов в исполкомах Советов. Не был урегулирован вопрос о количестве отделов и круг их полномочий. Многие отделы, исполняющие одни и те же функции в разных регионах РСФСР, назывались по-разному. Причинами такой разнородности отделов является тот факт, что длительное состояние Гражданской войны и иностранной интервенции в России не позволили проводить эффективные мероприятия по укреплению вертикали власти.

Однако вопросы разграничения полномочий между центром и регионами в различных сферах деятельности становились все актуальнее. Это требовало принятия различных положений и инструкций, дающих возможность, во-первых, построить структуру местных органов власти, во-вторых, привести в порядок систему выборов в местные Советы 
и, в-третьих, регламентировать имущественные и финансовые права местных органов.

Вопрос о том, каким образом должны формироваться Советы и какие задачи стоят перед ними, обсуждался на VII Всероссийском съезде Советов 5-9 декабря 1919 г. В итоговом документе: «О Советском строительстве» говорилось о том, что Советы должны работать не только как аппарат агитации и осведомления, но и как деловой механизм. Это означало, что местные Советы являются не просто отделом центральной власти, а должны быть таким органом власти, который наделен определенными полномочиями для решения задач повседневной жизни на отведенной ей территории. Кроме этого, Всероссийскому Центральному Исполнительному Комитету (ВЦИК) поручалось разработать положения об организации сельских советов и волостных исполнительных комитетов. Разработка данного положения диктовались условиями, которые происходили внутри страны. К 1920 г. вопрос скорейшего восстановления страны и организации советской власти на местах встал очень остро. Данные положения были приняты ВЦИК 15 февраля 1920 г. [1] и 18 марта 1920 г. [2].

Согласно ст. 1 декрета ВЦИК от 15 февраля 1920 г. сельские Советы являлись высшими органами власти в пределах их ведения и в границах обслуживаемой им местности. Определялись условия создания и сроки работы сельсоветов. Кроме этого, были установлены предметы ведения сельских Советов во всех областях жизни общества. Так, Советы были обязаны контролировать выполнения всех указов высших органов советской власти, следить за правопорядком, повышать уровень хозяйственного и культурного уровня населения на своей территории. Кроме того, на плечи сельских Советов возлагались задачи привлечения населения к строительству социализма на данной местности и отчета о своей деятельности перед избирателями [1]. В основном делалась ставка на контроль всех распоряжений и указов вышестоящих органов, учет, содействие, наблюдение за той или иной областью жизни общества.

Приблизительно такая же картина о предметах ведения Советов была и в положении о Волостных исполнительных комитетах. Волостной исполнительный комитет является в период между съездами высшим органом власти в пределах его ведения и в границах волости. Избирался сроком на 6 месяцев волостным съездом Советов в количестве: трех в волостях до 5000 жителей, четырех - в волостях до 10 000, пяти — в волостях до 15000 и шести - семи в волостях свыше 15000 жителей [2].

Все эти меры стали первым шагом строительства государственного управления. Следующим этапом стал проходивший с 22 по 29 декабря 1920 г. VIII Всероссийский съезд Советов. В постановлении были обозначены взаимоотношения между центральной и местной властью. Так, например, постановления местных Съездов Советов могли быть отме- 
няемы лишь вышестоящими Съездами, их Исполнительными Комитетами, Всероссийским Центральным Исполнительным Комитетом или его Президиумом. Кроме того, вслед за Советами в селах необходимо было решить вопросы управления в городах. На VIII Всероссийском съезде Советов было принято решение образовать во всех поселениях городского типа городские Советы.

Первые реальные шаги можно увидеть в циркулярном постановлении ВЦИК от 8 февраля 1921 г. Было предложено всем Губернским исполнительным комитетам восстановить и организовать городские Советы (Горсоветы) в тех уездных центрах и заштатных городах, которые бездействовали во время гражданской войны или не были образованы вовсе. Также ставилась задача привести в исполнение Постановление VII Съезда Советов об образовании Советов в фабрично-заводских поселках [7].

При городских исполкомах поручалось создать отделы: управления, народного образования, здравоохранения, труда и коммунальный. Чуть позже 10 марта 1921 г. ВЦИК и Народный комиссариат внутренних дел принимают циркулярное письмо о работе городских Советов [9]. В нем даются рекомендации о создании и организации работы Советов.

Однако местные Советы постепенно превращались в подконтрольные органы управления центральной власти. Советам были отведены только чисто номинальные функции, а те права и обязательства, которые согласно заявлениям большевиков, должны были получить как органы самоуправления, передавались высшим и партийным органам. Кроме того, как отмечали сами большевики, увеличивалась бюрократизация местных органов.

Новая экономическая политика, начавшаяся с замены продразверстки продналогом, затронула промышленность, финансовую сферу и т.д. Это в свою очередь повлияло и на работу местных Советов. Увеличивалась роль Советов в управлении хозяйством, в мелкой промышленности и в распределении бюджета. Фактически вся средняя и мелкая промышленность находилась под контролем местных Советов. Вместе с тем Советы получили возможность проведения самостоятельных хозяйственных операций, заниматься организацией своих предприятий, заключения концессий, выпуска коммунальных займов и т.д. Все это в итоге потребовало от центральной власти пересмотра нормативных документов о местных Советах. Результатом такой деятельности стало принятие целого пакета документов. ВЦИК принял Положения:

1) О Советах губернских, уездных и заштатных городов и поселков городского типа;

2) Об уездных Советах и их исполнительных комитетах;

3) О волостных Советах и исполнительных комитетах;

4) О сельских Советах. 
Позднее ВЦИК принял положение о губернских съездах Советов и Губернских исполнительных комитетах [6]. В постановлении ВЦИК от 26 января 1922 г. «О сельских Советах» в главе об организации Советов предпринимается попытка центральной власти уменьшить количество Советов. Об этом говорит и тот фракт, что для создания на той или иной территории органа местной власти необходимо уже не менее 400 жителей и избирается 1 депутат на каждые 200 человек населения, но не менее 25 депутатов (300 жителей, 100 человек и 50 депутатов соответственно) [5]. В ст. 91 постановления ВЦИК от 26 января 1922 г. изменению подвергался срок работы и количество членов. Теперь исполком избирался на один год в количестве 3 членов [4].

Имелись недостатки в положениях о губернских и уездных Советах. Важные и крайне острые для местных учреждений вопросы остались не урегулированными. Например, в структуре губернского исполкома не было проведено разграничение функций между пленумом и президиумом, не сорормулированы административные полномочия губернской власти в отношении нижестоящих уездных исполкомов [10].

Все недочеты по работе уездных советов пытались учесть при составлении нового положения об уездных Советах. В постановлении ВЦИК положение об уездных Советах от 16 октября 1924 г. были прописаны взаимоотношения между уездом и губерний. Был расширен круг введения исполнительного комитета. Кроме этого, расписаны обязанности и возможности отделений исполнительного комитета.

Дальнейшим изменениям подверглось и положение об сельских Советах. Так в мае 1927 г. ВЦИК и СНК приняли постановление об изменении ст. 4, 14, 25 положения о сельсоветах, в котором сельсовет могли, пользуясь правами юридического лица, принимать на себя обязательства и вступать в хозяйственно-договорные отношения в пределах, устанавливаемых особой инструкцией ВЦИК. Кроме того, уменьшалось максимальное количество депутатов. Теперь их может быть не более 50 человек.

Тем не менее все эти меры не смогли решить проблемы, которые стояли в начале 1920-х гг. Бюрократизация системы, сращивания местных советов с партийными органами принял широкие размахи. «К концу 1920-х гг. высшая партийно-государственная власть, используя различные меры административного воздействия и политических репрессий, превратила советы в придаток бюрократической системы, сохраняя лишь видимость «советского парламентаризма», - отмечает один из авторов [8].

Сложный путь проходила и избирательная система. Первые правила выборов в Советы были прописаны в Конституции 1918 г. Позже в положениях разных административных единиц прописывалось количество представителей в тот или иной Совет и срок работы депутатов. Отдельного документа, в котором прописывались правила проведения выборов 
появился в августе 1922 г. В постановлении ВЦИК от 31 августа 1922 г. говорилось о создании избирательных комиссий, которые должны регулировать процедуру выборов. Также прописывались граждане, которые имели и были лишены право голоса.

Так согласно инструкции, в категорию граждан, лишенных право голоса, входили лица, которые использовали наемный труд с целью получения прибыли, лица, занимающиеся коммерческой деятельностью, служите церкви, служащие и агенты бывшей полиции, особого корпуса жандармов и охранного отделения, а также члены царствовавшего в России дома. Кроме того, в такую категорию входили недееспособные граждане и лица отбывающие наказания в местах заключения [3].

В дальнейших постановлениях ВЦИК совершенствовались пункты инструкций, в которых оговаривались граждане, имеющие и лишенные право голоса. Однако выборы 1924 г. показали низкую активность граждан участвовать в выборах. Пытаясь решить данный вопрос, власти в инструкциях президиума ВЦИК от 1925 г. устанавливают планку, согласно которой выборы признавались несостоявшиеся. Эта планка составила 35 \% от общего числа избирателей. Кроме того, добавились статьи, в которых прописывали рассмотрения жалоб граждан на лишение их избирательного права. Все это стало основой для дальнейшего усовершенствовании системы выборов в Советы. К 1926 г. В инструкции о выборах в Советы уже было 66 статей (против 34 в 1922 г.).

Подводя итоги вышесказанному необходимо отметить следующее: в 20-е гг. в РСФСР проходил очень сложный путь становления и развития системы местных органов власти. Придя к власти, большевики обладали только теоретическими знаниями о построении высшей и местной власти. Только время и практика показала, в каком направлении нужно двигаться советской власти, чтобы построить хорошо слаженную систему управления.

\section{Список использованной литературы и источников}

1. Декрет ВЦИК от 15 февраля 1920 г. «О сельских Советах (Положение)» // Собрание узаконений и распоряжений правительства за 1920 г. - М., 1943. C. 87-92.

2. Декрет ВЦИК от 18 марта 1920 г. «О волостных исполнительных комитетах (Положение)» // Собрание узаконений и распоряжений правительства за 1920 г. - М., 1943. - С. 147-149.

3. Декрет ВЦИК от 31 августа 1922 г. «Инструкция о перевыборах городских и сельских советов и о созыве волостных, уездных и губернских съездов советов» // Собрание узаконений и распоряжений Рабочего и Крестьянского правительства РСФСР (СУ РСФСР). - 1922. — № 56. - Ст. 706.

4. Постановление ВЦИК от 26 января 1922 г. «Положение о Волостных Съездах Советов и Волостных Исполнительных Комитетах» // Собрание узаконений и распоряжений Рабочего и Крестьянского правительства РСФСР (СУ РСФСР). - 1922. — № 10. - Ст. 92. 
5. Постановление ВЦИК от 26 января 1922 г. «Положение о сельских советах» // Собрание узаконений и распоряжений Рабочего и Крестьянского правительства РСФСР (СУ РСФСР). — 1922. — № 10. - Ст. 93.

6. Постановление ВЦИК от 31 октября 1922 г. «Положение о губернских съездах советов и губернских исполнительных комитетах» // Собрание узаконений и распоряжений Рабочего и Крестьянского правительства РСФСР (СУ РСФСР). — 1922. — № 72-73. - Ст. 907.

7. Постановление Президиума ВЦИК от 8 февраля 1921 г. «Об организации городских Советов рабочих и крестьянских депутатов» // Собрание узаконений и распоряжений правительства за 1920 г. - М., 1944. - С. 117-118.

8. Тропов И. А. Местные советы в 1917-1920-е гг.: особенности структуры и деятельности / И. А. Тропов // Вестник Ленинградского государственного университета им. А.С. Пушкина. - 2008. - № 3. - С. 81-92.

9. Циркулярное письмо ВЦИК и Народного комиссариата внутренних дел от 10 марта 1921 г. о работе городских Советов // Декреты Советской власти. Т. XIII. 1 февраля - 31 марта 1921 г. - М.: Политиздат, 1989. - С. 94-96.

10. Ящук Т. Ф. Реформы местного управления в РСФСР в 1920-е год / T. Ф. Ящук // Lex Russica. — 2017. — № 10 (131). — C. 171-186.

\section{Информация об авторах}

Казарин Виктор Николаевич - доктор исторических наук, профессор кафедры конституционного права и теории права, Юридический институт, Иркутский государственный университет, 664003, г. Иркутск, ул. К. Маркса, 1; e-mail : kazarinvik@yandex.ru

Силянкин Никита Валентинович - магистрант, Исторический факультет, Иркутский государственный университет, 664025, г. Иркутск, ул. Чкалова, 2; e-mail nikita.silyankin@yandex.ru

\section{Authors}

Victor N. Kazarin - Doctor of History, Professor, Chair of Constitutional Law and the Theory of Law, Law Institute, Irkutsk State University, 1 K. Marx St., 664003, Irkutsk, Russia; e-mail: kazarinvik@yandex.ru.

Nikita V. Siliankin - Master Degree Student, History Faculty, Irkutsk State University, 2 Chkalov St., 664025, Irkutsk, Russia; e-mail: nikita.silyankin@yandex.ru. 